\title{
Use of the Nursing Outcomes Classification - NOC to assess the knowledge of patients with venous ulcer
}

\author{
Uso da Nursing Outcomes Classification - NOC para avaliar o \\ conhecimento de pacientes com úlcera venosa \\ Uso de la Nursing Outcomes Classification - NOC para evaluar \\ el conocimiento de los pacientes con úlcera venosa
}

\author{
Viviane Maria Osmarin ${ }^{a}$ \\ Fernanda Guarilha Bonia \\ Taline Bavaresco ${ }^{a}$ \\ Amália de Fátima Lucena $a^{a, b}$ \\ Isabel Cristina Echer ${ }^{\mathrm{a}, \mathrm{c}}$
}

How to cite this article: Osmarin VM, Boni FG, Bavaresco T, Lucena AF, Echer IC. Use of the Nursing Outcomes Classification - NOC to assess the knowledge of patients with venous ulcer. Rev Gaúcha Enferm. 2020;41(esp):e20190146 doi: https://doi.org/10.1590/19831447.2020.20190146 a Universidade Federal do Rio Grande do Sul (UFRGS), Escola de Enfermagem, Programa de Pós-Graduação em Enfermagem. Porto Alegre, Rio Grande do Sul, Brasil.

${ }^{-}$Hospital de Clínicas de Porto Alegre (HCPA), Comissão do Processo de Enfermagem. Porto Alegre, Rio Grande do Sul, Brasil.

Hospital de Clínicas de Porto Alegre (HCPA) Serviço de Enfermagem Cardiovascular, Nefrologia e Imagem. Porto Alegre, Rio Grande do Sul, Brasil.

\section{ABSTRACT}

Objective:To evaluate the knowledge of patients with venous ulcers (VU) on their chronic disease, treatment, and prevention of complications, according to the Nursing Outcomes Classification-NOC.

Methods: This is a cross-sectional study conducted between 2017 and 2018 in a Brazilian hospital. The sample consisted of 38 patients with VU attended in outpatient nursing consultations. The study analyzed sociodemographic, clinical and nine indexes from the Knowledge: Chronic Disease Management (1847) of the NOC, assessed using a five-point Likert scale, analyzed using descriptive statistics.

Results: The mean of the result Knowledge: Chronic Disease Management (1847) was 3.56 1 1.42. The clinical index Procedures involved in treatment regimen had the highestmean $4.18 \pm 0.21$, followed by Pain management strategies with $3.92 \pm 0.27$. In the association between knowledge and healing, the best scores were in patients with at least one healedVU.

Conclusion: The knowledge of the patients was moderate and it was necessary to promote educational actions according to individual demands. Keywords: Varicose ulcer. Wound healing. Standardized nursing terminology. Knowledge. Outcome assessment (Health care).

\section{RESUMO}

Objetivo: Avaliar o conhecimento de pacientes com úlcera venosa (UVe) sobre a sua doença crônica, tratamento e prevenção de complicações, segundo a Nursing Outcomes Classification - NOC

Métodos: Estudo transversal realizado entre 2017 e 2018 em hospital brasileiro. A amostra foi de 38 pacientes com UVes atendidos em consulta de enfermagem ambulatorial. Foram analisados dados sociodemográficos, dínicos e nove indicadores do resultado NOC Conhecimento: Controle da Doença Crônica (1847) avaliados por escala Likert de cinco pontos. A análise foi estatística descritiva.

Resultados: A média do resultado Conhecimento: controle da doença (1847) foi 3,56 1,42, o indicador clínico Procedimentos envolvidos no regime de

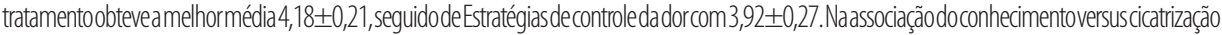
os melhores escores foram em pacientes com pelo menos uma UVe cicatrizada.

Conclusões: 0 conhecimento dos pacientes mostrou-semoderado havendo necessidade de promover ações educativas conformedemandas individuais. Palavras-chave: Úlcera varicosa. Cicatrização. Terminologia padronizada em enfermagem. Conhecimento. Avaliação de resultados (Cuidados de saúde).

\section{RESUMEN}

Objetivo: Evaluar el conocimiento de pacientes con úlcera venosa (UVe) en su enfermedad crónica, tratamiento y prevención de complicaciones, según la Nursing Outcomes Classification-NOC.

Métodos: Estudio transversal entre 2017y 2018 en hospital brasileño. La muestra consistió en 38 pacientes con UVes atendidos en consultas de enfermería ambulatorias. Analizamos los conocimientos sociodemográicicos, clínicosy nueve indicadores NOC Conocimiento: Control de la Enfermedad Crónica ( 1847) evaluada por escala Likert de cinco puntos. El análisis fue estadístico descriptivo.

Resultados: E promedio del resultado Conocimiento: Control del la Enfermedad Crónica (1847) fuede3,56 11,42, los indicadores clínicos Procedimientos del régimen de tratamiento obtuvieron el mejor promedio de 4,18 $\pm 0,21$, seguidos del Estrategias de control del dolor con 3,92 0 0,27. En la asociación del conocimiento versus curación, se encontraron mejores puntuaciones en pacientes con menos una UVe sanada.

Conclusiones: El conocimiento de los pacientes demostró ser moderado, con necesidad de promover acciones educativas de acuerdo con las demandas individuales.

Palabras clave: Úlcera varicosa. Cicatrización de heridas. Terminología normalizada de enfermería. Conocimiento. Evaluación de resultado (Atención de salud). 


\section{口INTRODUCTION}

Chronic venous insufficiency $(\mathrm{CVI})$ is a group of clinical manifestations caused by changes in the reflux and/or obstruction of the lower-limb venous system ${ }^{(1-2)}$. Some of the risk factors for the development of this disease stand out, such as: advanced age, female sex, number of pregnancies, obesity, and family history. Clinical manifestations include the presence of dilated veins, edema, pain, hyperpigmentation, eczematous dermatitis, and venous ulcers (VUs) in the affected limb (the latter is considered the most severe degree of $(\mathrm{VI})^{(1-2)}$.

The worldwide prevalence of UVs is from $1 \%$ to $3 \%$ in the population over 65 years of age, with a strong social and economic impact. The treatment consists in the control of venous hypertension through the use of compressive therapy, the strengthening of lower-limb muscles, and walking and resting in alternate turns ${ }^{(3-4)}$. In addition, the treatment includes topical care to the wounds using different types of dressing, according to the tissues in evidence. Healthy lifestyles and the control of other comorbidities influence in the therapeutic success and in the prevention of complications $^{(3-5)}$. Adjunct therapies are also used to fasten the scarring process, and low-level laser therapy (LLLT) is strongly recommended ${ }^{(6-7)}$.

In many situations, the patients face hardships in the treatment of VUs, which can be related to the lack of knowledge regarding the chronic disease, its treatment, and the way in which healthcare must be carried out. The knowledge of patients is known to offer them a higher chance of self-management, and the capacity to control and understand their health conditions and the factors that influence the scarring of the wound ${ }^{(4,8)}$.

There are evidences that associate patients who are committed and participate in their own therapeutic processes with the knowledge these patients have regarding the chronic disease, and, consequently, to the control of risk factors and an efficient management of actions to prevent complications such as delays in scarring and relapses ${ }^{(7,9)}$. In this context, the role of the nurse as a mediator in the teaching/learning process is relevant, so that patients can develop autonomy and become independent regarding their daily care.

Studies identify the importance of the nurse in the follow-up process, and in the offering of guidance that aims to guarantee the autonomy of patients in the performance of their self-care, and the prevention of wound recurrence ${ }^{(7-10)}$. However, there is a lack of studies that evaluate the knowledge of patients with VUs about their disease, its treatment, and the care necessary to manage and recover their health with accurate measuring instruments.

In this setting, the Nursing Outcomes Classification (NOC) presents the result Knowledge: Chronic Disease Management (1847), with clinical indexes that are applicable in the evaluation of the knowledge of patients in this field of care ${ }^{(11)}$. The NOC, through its indexes, aims to assess patients' situations so that the nurses can plan their interventions, which include guidance regarding health education.

Therefore, considering the relevance of assessing the knowledge of patients' when it comes to caring for their disease and performing its therapy, as well as to the lack of studies on the application of the Nursing Result indexes from the NOC's Knowledge: Chronic Disease Management (1847) on patients with VUs due to CVI, this study was designed with the hypothesis: "a higher knowledge of patients regarding the disease and its treatment favors the scarring process of VUs".

Thus, this research aims at assessing the knowledge of patients with $\mathrm{VU}$ s regarding their chronic disease, its treatment, and how to prevent complications, according to the NOC.

\section{METHODS}

This is a cross-sectional study, carried out in an outpatient nursing clinic, specialized in wound care, in a large-sized university hospital in the south of Brazil, from September 2017 to August 2018.

The sample of the study was made up of 38 patients with 78 VUs, from a Randomized Clinical Trial $(R C T)^{(7,12)}$ that tested the LPLT as an adjunct treatment to the conventional one. During the RCT, patients were monitored in weekly nursing consultations, until they were discharged due to the scarring of the ulcer, or after 16 weeks of treatment had been completed. During consultation, the patients received guidance about the adequate treatment of the wound, the importance of appropriately using the compressive therapy, doing the exercises, and elevating the lower limbs. They also received guidance for the control of other comorbidities and the management of healthy living habits, especially regarding adequate food intake and hydration. In addition, they received pamphlets which discussed relevant aspects for the control of the pathology and the care of the VUs, as well as written guidance from the nurse, when necessary. 
The study included patients who had participated in both RCT groups and went to the nursing consultation that was carried out six months after they were finished. No exclusion criterion was used.

The data in this study was collected by the same researchers who were carrying out the nursing consultations, using an instrument specifically developed to do so, which contained clinical variables, whether or not there was or had been VU scarring, and assessments of the conventional care, such as: walking, lower-limb elevation, lower-limb isometric exercises, and compressive therapy. The sociodemographic variables had already been collected into a database.

The tool used to assess patient knowledge was the result Knowledge: Chronic Disease Management, from the NOC (1847). It includes 30 clinical indexes ${ }^{(11)}$, from which nine were used. They had been selected and validated according to a consensus of specialists in a previous study ${ }^{(13)}$, and their conceptual and operational definitions had been elaborated. The evaluated indexes were: Causes and contributing factors (184701); Benefits of disease management (184703); Signs and symptoms of chronic disease (184704); Strategies to prevent complications (184707); Strategies to balance activity and rest (184708); Strategies to manage pain(184709); Procedures involved in treatment regimen (184717); Personal responsibilities for treatment regimen (184718); and Financial resources for assistance (184725). These indexes, as prescribed by the NOC, were scored from one to five using a Likert scale, in which 1 meant "no knowledge", 2 "limited knowledge", 3 "moderate knowledge", 4 "substantial knowledge", and 5 "vast knowledge".

Data was analyzed using the software Statistical Package for the Social Sciences (SPPS), version 23.0. The categorical variables were expressed using percentages and absolute value, and the continuous ones using mean and standard deviation. To compare the means, Student's T-test was used, with a significance level of $5 \%(p<0.05)$.

This study was approved by the Research Ethics Committee of the institution, under protocol 150634 and CAEE 53362816.1.0000.5327. All participants signed the Free and Informed Consent Form.

\section{口RESULTS}

This research included 38 patients, from which 20 presented at least one healed wound, while 18 had no healed VUs. These patients had a total of $78 \mathrm{ul}$ cers, 30 healed VUs and 48 unhealed VUs. Their mean age was $63.7( \pm 11.4)$ and their mean body mass index (BMI) was overweight $31( \pm 5.4) \mathrm{kg} / \mathrm{m}^{2}$. Twenty-five were female (66\%), 31 (82\%) white, 23 (60\%) married, $26(70 \%)$ had up to eight years of formal education, and 25 (66\%) used analgesic medication related to the VUs. Twenty-seven patients (71\%) cared for themselves in their homes and 25 (66\%) went alone to the consultations.

Among the most common comorbidities, 24 (63\%) had hypertension, 12 (32\%) had hypercholesterolemia, 6 (16\%) had diabetes mellitus, and 4 (11\%) had depression. Thirteen (34\%) patients had smoked before or were smokers and 3 (8\%) consumed alcohol every week.

Patients had a moderate knowledge, with a score of 3.56 in the assessment of the result Knowledge: Chronic Disease Management (1847). Regarding the clinical indexes, the Procedures involved in treatment regimen (184717) had the highest mean, with a score of 4.18, indicating a substantial amount of knowledge. Causes and contributing factors (184701) and Personal responsibilities for treatment regimen (184718), on the other hand, showed a limited knowledge, with the same mean score of 2.86, the lowest one. The other indexes showed that patients had moderate knowledge, according to Table 1.

Patients were also questioned regarding the actions carried out to control the disease and prevent complications. It should be noted that most patients took measures to care for the pathology and control it, as Image 1 shows.

In the association of knowledge with scarring, it was found that patients (20) with at least one healed $V U$ had a better mean result in the NOC than those who did not have healed ulcers, with a statistically significant difference $(p=0.021)$. In addition, the clinical indexes Causes and contributing factors (184701) and Pain control strategies (184709) showed a statistically significant difference between the groups: $p=0.002$ and $p=0.011$, respectively. However, the indexes Strategies to prevent complications (184707); Procedures involved in treatment regimen (184717); Signs and symptoms of chronic disease (184704); Personal responsibilities for treatment regimen (184718); and Financial resources for assistance (184725) did not show statistically significant differences, although their mean scores were higher among patients with at least one healed VU. Said data is shown in Table 2. 
Osmarin VM, Boni FG, Bavaresco T, Lucena AF, Echer IC

Table 1 - Mean scores for the nursing result Knowledge: Chronic Disease Management (1847) and its indexes in patients with VUs ( $n=38)$, Porto Alegre, RS, 2018

\section{Nursing Result}

Knowledge: Chronic Disease Management (1847)

\section{Indexes}

Procedures involved in treatment regimen (184717)

Strategies to manage pain (184709)

Financial resources for assistance (184725)

Strategies to prevent complications (184707)

Strategies to balance activity and rest (184708)

Benefits of disease management (184703)

Signs and symptoms of chronic disease (184704)

Causes and contributing factors (184701)

Personal responsibilities for treatment regimen (184718)

Source: Research data, 2018

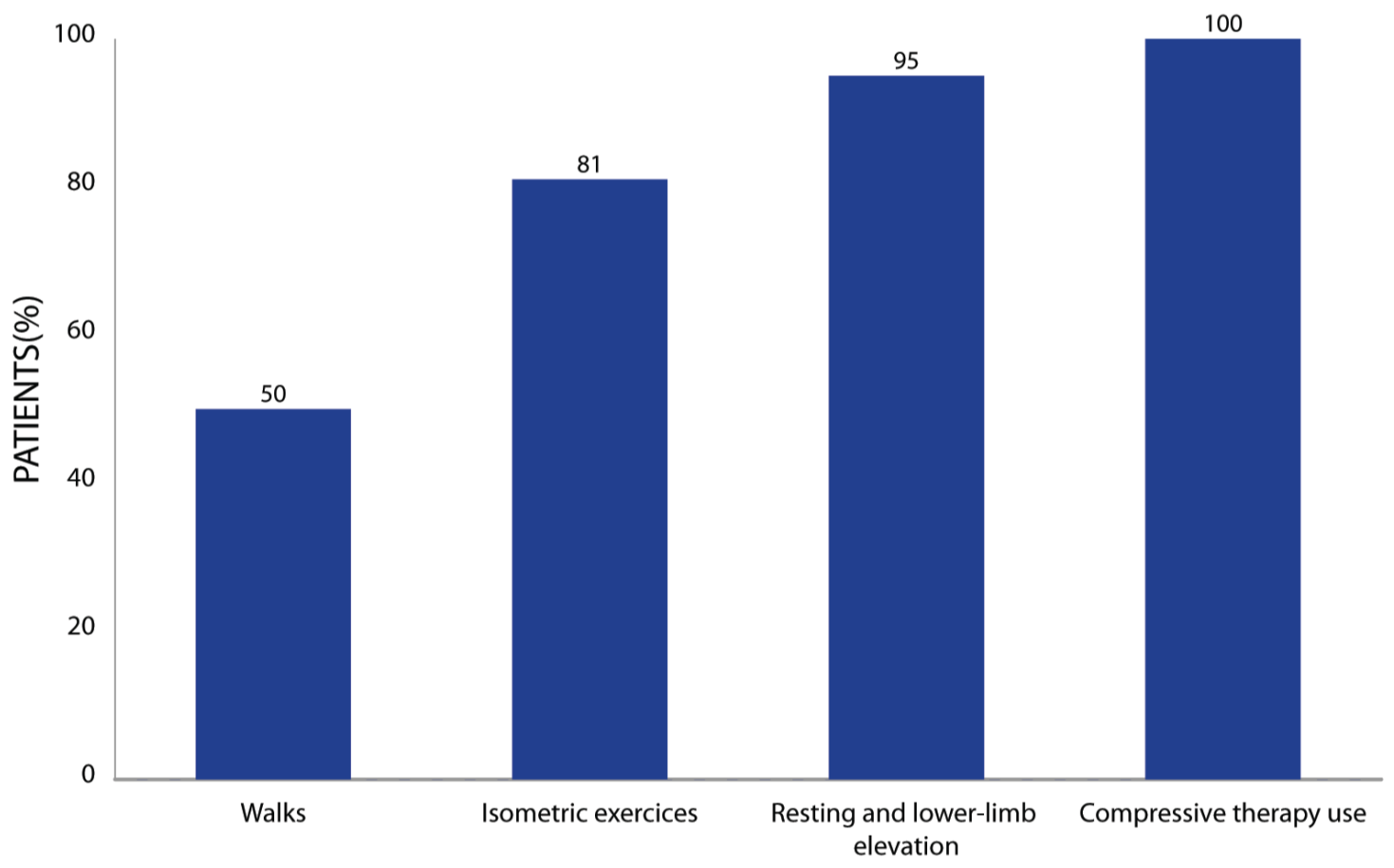

\section{CONVENTIONAL CARE FOR CVI TREATMENT}

Image 1 - Conventional care carried out by the patients to treat the CVI ( $n=38)$, Porto Alegre, RS, 2018 Source: Research data, 2018 
Table 2 - Mean scores for the NOC nursing result Knowledge: Chronic Disease Management (1847) and its indexes in patients with at least one healed VUs $(n=20)$ when compared to those who presented no healed VUs $(n=18)$, Porto Alegre, RS, 2018

\begin{tabular}{|c|c|c|c|}
\hline Nursing Result & $\begin{array}{l}\text { Patients with } \\
\text { healed VUs* }\end{array}$ & $\begin{array}{l}\text { Patients with } \\
\text { unhealed VUs* }\end{array}$ & $p^{* *}$ \\
\hline Knowledge: Chronic Disease Management (1847) & $3.81(0.12)$ & $3.30(0.17)$ & 0.021 \\
\hline \multicolumn{4}{|l|}{ Indexes } \\
\hline Procedures involved in treatment regimen (184717) & $4.45(0.18)$ & $3.89(0.24)$ & 0.070 \\
\hline Strategies to manage pain (184709) & $4.40(0.24)$ & $3.39(0.29)$ & 0.011 \\
\hline Financial resources for assistance (184725) & $4.10(0.17)$ & $3.72(0.24)$ & 0.262 \\
\hline Strategies to prevent complications (184707) & $4.00(0.24)$ & $3.67(0.28)$ & 0.370 \\
\hline Benefits of disease management (184703) & $3.80(0.24)$ & $3.33(0.34)$ & 0.270 \\
\hline Strategies to balance activity and rest (184708) & $3.60(0.21)$ & $3.72(0.24)$ & 0.703 \\
\hline Signs and symptoms of chronic disease (184704) & $3.55(0.25)$ & $3.06(0.27)$ & 0.195 \\
\hline Causes and contributing factors (184701) & $3.40(0.23)$ & $2.28(0.25)$ & 0.002 \\
\hline Personal responsibilities for treatment regimen (184718) & $3.00(0.22)$ & $2.72(0.25)$ & 0.420 \\
\hline
\end{tabular}

\section{DISCUSSION}

Assessing the knowledge of patients with VU using the clinical indexes of NOC's result Knowledge: Chronic Disease Management (1847) becomes relevant for nursing practice, since literature is lacking when it comes to this theme. Only two researches were identified which evaluated the knowledge about the care offered to patients with cardiac insufficiency using the $\mathrm{NOC}^{(9,14)}$.

Most patients were elders, female, and had up to eight years formal education. A research from Shanghai found that VUs are the most common cause of chronic wounds in elders above 60 years of age ${ }^{(15)}$. A Brazilian study in a university hospital with a similar sample sought to assess the recurrence of VUs in patients with previous healed wounds during a period of ten years. There was no association between the educational level and the recurrence of VUs. However, the recurrence was more frequent in patients with a lower educational level ${ }^{(16)}$. From this perspective, nurses must understand the singularities of each patient and use their technical and scientific abilities to carry out interventions based on the patient's level of knowledge, in order to offer an opportunity for understanding and learning.

Most patients were overweight and used analgesics to deal with the pain of the pathology and of the VUs. A systematic review found that patients with VUs are more likely to be overweight or obese, in addition to having difficulties to reach an ideal BMI, since the pain limits their mobility and leads to changes in their life habits ${ }^{(17)}$. A Brazilian qualitative study, with a sample of ten patients, found that self-care is a result of the bond between health professionals, patients, and the support of family members, a triad that is essential for the work related to healthcare to be shared ${ }^{(18)}$. The nurse must monitor, stimulate, and encourage patients and family members to continuously care for the VUs and control the CVI, also encouraging them to adopt healthy habits, which are essential for patients to live with chronic pathologies, and diminish the discomforts related to these diseases.

Knowledge about the disease and its treatment may contribute for health-related self-care. Patients showed moderate knowledge (mean score 3.56) on the indexes of the result Knowledge: Chronic Disease Management (1847), despite having a weekly follow up in nursing consultations, in which health education took place orally, in writing, and through the delivery of educational materials. Therefore, this study suggests for the guidance to be increased and addressed according to the needs of the patients, its results being periodically evaluated using specific standardized instruments, to guarantee that patients understood the advices received. In this study, the use of the NOC for the 
nursing assessment of patients was found viable and useful, since its clinical indexes made it possible to objectively and effectively measure the knowledge of patients.

A Brazilian study with 101 patients with VUs found that the greatest difficulty in the treatment was adhering to the compressive therapy and to the regular exercises, concluding that the patient's knowledge is important for them to engage in home care. The success of the therapy depends essentially on the actions of the patient ${ }^{(19)}$. Therefore, the nurse must be involved in this process through innovative strategies that can sensitize the patient to reflect on the importance of the knowledge of the disease, so that they can effectively assume their own daily care.

The patients showed substantial knowledge (4.18) about Procedures involved in treatment regimen (184717), indicating that they understand the care they need to have regarding dressing wounds and controlling CVI, themes directly connected to the use of compressive therapy, exercising to strengthen lower-limb muscles, and resting. However, difficulties in identifying individual needs regarding care, as well as those found during the weekly follow-up guidance, when added to the six-month interval between the sessions and the evaluation, may have interfered in the knowledge of the patients.

Regarding Strategies to balance activity and rest (184708), the knowledge was found to be moderate, with a mean score of 3.65. This index is directly linked to walking, exercising, elevating lower limbs, and how to alternate between activities and resting. More than half the patients studied, as image 1 has shown, carried out actions to control the pathology. A Brazilian study evaluated the knowledge of patients about cardiac insufficiency and found better scores after a six-month follow-up ${ }^{(12)}$.

An integrative review sought to find evidences related to the standard VU treatment and CVI control, finding, as its results, the use of adequate lower-limb compression techniques and the search for adjunct materials to accelerate the scarring process ${ }^{(3)}$. The knowledge of professionals regarding the best evidence-based practices leads to quality assistance and provides satisfaction to the patient and to the healthcare team. However, health professionals are not always available and ready to carry out educational actions with the patients and their families.

The clinical indexes Causes and contributing factors (184701) and Personal responsibilities for treatment regimen (184718) showed a limited knowledge, with a mean score of 2.86. That shows that patients are unclear regarding the causes of $\mathrm{VU}$ s and about what their own responsibilities are. Health education interventions have been showing the benefits of recurrence prevention and of the involvement of patients in their own treatment ${ }^{(7)}$. This data points at the need of raising the awareness of patients, regarding continuous guidance about the disease, so that therapeutic success can be obtained.

While analyzing the knowledge of patients who presented at least one healed $\mathrm{VU}$, it was found that their result Knowledge: Chronic Disease Management (1847) had a statistically significant difference. The clinical indexes Causes and contributing factors (184701) and Pain control strategies (184709) also showed a statistically significant difference, meaning that patients with at least one healed VU had better scores. A study carried out in the United States found that educating the patient is effective to increase their knowledge on the process of the disease and on their self-care, leading to the VUs to remain healed and diminishing the rates of recurrence ${ }^{(20)}$. The scarring can be inferred to have an association with the knowledge of patients regarding the disease and its care, something made clear by the systematic performance of conventional care.

The clinical indexes Strategies to prevent complications (184707); Procedures involved in treatment regimen (184717); Personal responsibilities for treatment regimen (184718); and Financial resources for healthcare (184725) had higher mean scores among patients with healed wounds. Therefore, scarring may be related to the knowledge about preventing complications, to the healthcare required by the therapy, to the responsibility of the patient, and to the resources they have to devote to the healthcare. A study found that nurses are the professionals who encourage the patients the most to perform self-care, in order to prevent complications and VU recurrence ${ }^{(8)}$. The development of continued education to patients regarding their chronic condition is essential and may be connected to wound healing and to the prevention of recurring VUs, which clearly shows that patients must assume the responsibility of carrying out their daily healthcare.

Therefore, it is essential for health professionals to acquire theoretical/practical knowledge, aimed at improving care and guidance, in order to educate the patient and favor the VUs healing process. It is also necessary to implement, in clinical practice, the systematic evaluation of the results of nursing interventions, so that therapeutic actions can be planned based on scientific evidences.

\section{CONCLUSIONS}

The Knowledge: Chronic Disease Management (1847) was moderate in patients with VU. The best mean scores were found in patients with at least one healed ulcer, showing the importance of knowledge for the process of 
tissue regeneration, and the need to invest in guidance according to the sociocultural needs of each individual. It should be reiterated that the knowledge of patients about chronic diseases allows them to manage their own health care with efficacy. Nurses, however, must evaluate the knowledge of patients about educational measures, checking whether these are being understood and if it is necessary to reiterate any information.

The results also restated the importance of assessing the efficiency of nursing interventions. The NOC showed itself as an important tool for standardized evaluation, making it possible to identify the level of knowledge of patients regarding their disease and its treatment.

As a limitation of this study, it stands out that the assessment of clinical indexes from the NOC result Knowledge: Chronic Disease Management (1847) was carried out at a single moment, in only one center of clinical practice. This study may contribute for the improvement of teaching, research, healthcare, and nursing management, since the use of clinical indexes to assess the knowledge of patients can help planning effective interventions and guide the elaboration of more refined assistance protocols. It should also be highlighted that it is necessary to include patients and their families in the treatment of VUs, so that they can understand and continuously execute the therapeutic process, since this is a chronic pathology.

\section{Q REFERENCES}

1. Sociedade Brasileira de Angiologia e Cirurgia Vascular. Insuficiência venosa crônica: diagnóstico e tratamento. São Paulo: SBACV; 2015 [cited 2019 Feb 15]. Projeto Diretrizes SBACV. Available from: http://www.sbacv.org.br/lib/media/ pdf/diretrizes/insuficiencia-venosa-cronica.pdf

2. Gordon P, Widener JM, Heffline M. Venous leg ulcers: impact and dysfunction of the venous system. JVasc Nurs. 2015;33(2):54-9. doi: https://doi.org/10.1016/j. jvn.2015.01.002

3. Xie T, Ye J, Rerkasem K, Mani R. The venous ulcer continues to be a clinical challenge : an update. Burns Trauma. 2018;6:18. doi: https://doi.org/10.1186/ s41038-018-0119-y

4. Silva JC. Gestión de cuidado de las personas con úlcera venosa: una revisión integrativa. Cultura de los Cuidados. 2016;20(46):157-64. doi: https://doi. org/10.14198/cuid.2016.46.15

5. Echer IC, Osmarin, Santos CT, Bavaresco T, Boni FG, Lucena, AF. Avaliação e tratamento de lesões do sistema tegumentar. In: Bresciani HR, Martini JG, Mai LD, organizadoras. PROENF: Programa de Atualização em Enfermagem: Saúde do Adulto: ciclo 13. Porto Alegre: ArtMed/Panamericana; 2018. v. 3, p. 9-59.
6. Lima NEP, Gomes GDM, Feitosa ANA, Bezerra ALD, Sousa MNA. Laser therapy low intensity in wound care and practice nurses. Rev Enferm UFPI. 2018;7(1):50-6. doi: https://doi.org/10.26694/2238-7234.7150-56

7. Bavaresco $\mathrm{T}$. 0 efeito do laser de baixa potência no tratamento de úlceras venosas avaliado pela NOC: ensaio clínico randomizado [tese]. Porto Alegre (RS): Escola de Enfermagem, Universidade Federal do Rio Grande do Sul; 2018 [citado 2019 fev 15]. Disponivel em: https://lume.ufrgs.br/handle/10183/186135

8. Brown A. Self-care strategies to prevent venous leg ulceration recurrence. Pract Nurs. 2018;29(4):152-8.doi: https://doi.org/10.12968/pnur.2018.29.4.152

9. Azzolin KO, Lemos DM, Lucena AF, Rabelo-Silva ER. Home-based nursing interventions improve knowledge of disease and management in patients with heart failure. Rev Latino-Am Enfermagem. 2015 Feb;23(1):44-50. doi: https:// doi.org/10.1590/0104-1169.0144.2523

10. Lima LV, Sousa ATO, Costa ICP, Silva VDM. Conhecimento de pessoas com úlceras vasculogênicas acerca da prevenção e cuidados com as feridas. Rev Estima. 2013 [cited 2019 Feb 15];11(3). Available from: https://www.revistaestima.com.br/ index.php/estima/article/view/85

11. Moorhead S, Swanson E, Johnson M, Maas ML. Nursing Outcomes Classification (NOC): measurement of health outcomes. 6th ed. St Louis (MO): Elsevier; 2018.

12. Bavaresco T, Pires AUB, Moraes VM, Osmarin VM, Silveira DS, Lucena AF. Lowlevel laser therapy for treatment of venous ulcers evaluated with the Nursing Outcome Classification: study protocol for a randomized controlled trial. Trials. 2018;19:372. doi: https://doi.org/10.1186/s13063-018-2729-x

13. Osmarin VM, Bavaresco T, Lucena AF, Echer IC. Clinical indicators for knowledge assessment of venous ulcer patients. Acta Paul Enferm. 2018;31(4):391-8. doi: https://doi.org/10.1590/1982-0194201800055

14. Alvarenga SR, Carneiro CDS, Santos VB, Simone R, Moreira L. Instructional instrument of NOC outcomes: control knowledge of cardiac disease for patients with heart failure. Revista Eletr Enf. 2015;17(4). doi: https://doi.org/10.5216/ree.v17i4.26530

15. Sun X, Ni P, Wu M, Huang Y, Ye J, Xie T. Clinico epidemiological profile of chronic wounds in wound healing department in Shanghai. Int I Low Extrem Wounds. 2017;16(1):36-44. doi: https://doi.org/10.1177/1534734617696730

16. Borges EL, Ferraz AF, Carvalho DV, Matos SS de, Lima VL de AN. Prevention of varicose ulcer relapse: a cohort study Acta Paul Enferm. 2016;29(1):9-16. doi: https://doi.org/10.1590/1982-0194201600003

17. Barber GA, Weller CD, Gibson SJ. Effects and associations of nutrition in patients with venous leg ulcers: A systematic review. J Adv Nurs. 2018;74(4):774-87. doi: https://doi.org/10.1111/jan.13474

18. Garcia AB, Müller PV, Paz PO, Duarte ERM, Kaiser DE. Perception of users on selfcare of lower leg ulcers. Rev Gaúcha Enferm. 2018;39:22017-0095. doi: https:// doi.org/10.1590/1983-1447.2018.2017-0095

19. Liberato SMD, Araújo RO, Souza AJG, Marconato AMP, Costa IKF, Torres GV. Adesão ao tratamento de pessoas com úlceras venosas atendidas na atenção primária à saúde. Aquichan. 2017;17(2):128-39. doi: https://doi.org/10.5294/aqui.2017.17.2.2

20. Gonzalez A. The effect of a patient education intervention on knowledge and venous ulcer recurrence: results of a prospective intervention and retrospective analysis. Ostomy Wound Manage. 2017 [cited 2019 Feb 15];63(6):16-28. Available from: https://www.o-wm.com/article/effect-patient-educationintervention-knowledge-and-venous-ulcer-recurrence-results

Received: 04.26.2019

Approved: 06.27.2019 